\title{
Eating behaviors in a male and female community sample: psychometric properties of the DEBQ
}

\section{Comportamientos alimentarios en una muestra comunitaria de hombres y mujeres: propiedades psicométricas del DEBQ}

\author{
Ana Andrés \\ Faculty of Psychology, Education Sciences and Sport Blanquerna, Universitat Ramon Llull, Barcelona, Spain. \\ Camila Oda-Montecinos \\ School of Psychology, Universidad Católica del Norte, Antofagasta, Chile. \\ Carmina Saldaña \\ Department of Clinical Psychology and Psychobiology, University of Barcelona, Barcelona, Spain. \\ Institute for Research on the Brain, Cognition and Behavior (IR3C), University of Barcelona, Barcelona, Spain.
}

Rec (22 de junio de 2016) Acept (22 de marzo de 2017)

\begin{abstract}
The aim of this study was to assess the psychometric properties of the Dutch Eating Behavior Questionnaire (DEBQ) in a community sample of Chilean adults. The sample comprised 627 participants who completed a battery of questionnaires. The mean age of the sample was 36.07 years ( $\mathrm{SD}=12.49)$, and $66.2 \%$ of them were women. Mean body mass index (BMI) was $25.61 \mathrm{~kg} / \mathrm{m}^{2}(\mathrm{SD}=4.20)$. Item analysis suggested that one item yielded very low corrected item-total correlation. The internal structure analysis revealed that the threefactor model showed a good fit. Internal structure was adequate. A gender effect was found in DEBQ scores, and there was a positive significant association between BMI and DEBQ scores. The correlation analysis supported the adequate convergent validity of the scale. The present study provides evidence to support the adequate reliability and validity of the DEBQ when applied in a Chilean population.

Keywords: assessment; cross-validation; DEBQ; eating behavior; psychometric analysis.
\end{abstract}

\section{Resumen}

El objetivo de este estudio fue evaluar las propiedades psicométricas del Dutch Eating Behavior Questionnaire (DEBQ) en una muestra comunitaria de adultos chilenos. La muestra se compuso por 627 participantes que completaron una batería de cuestionarios. La media de edad fue de 36.07 años (DT=12.49), y el 66.2\% fueron mujeres. El índice de masa corporal (IMC) medio fue $25.61 \mathrm{~kg} / \mathrm{m}^{2}(\mathrm{DT}=4.20)$. Uno de los ítems presentó una inadecuada correlación ítem-total corregida. El análisis de la estructura interna mostró un buen ajuste al modelo de tres factores. La consistencia interna fue adecuada. Se detectó un efecto de género en las puntuaciones del DEBQ y hubo una asociación positiva significativa entre el IMC y las puntuaciones del DEBQ. El análisis de correlaciones puso de manifiesto la adecuada validez convergente de la escala. El presente estudio proporciona evidencia para apoyar la adecuada fiabilidad y validez del DEBQ cuando se aplica a población chilena.

Palabras clave: comportamiento alimentario; DEBQ; evaluación; propiedades psicométricas; validación cruzada.

\footnotetext{
Corresponding author: Camila Oda-Montecinos, School of Psychology, Universidad Católica del Norte, Av. Angamos 0610, Antofagasta, Chile, e-mail: camila.oda@ucn.cl,Tel.+56-55-2355846.

Acknowledgments: We would like to thank Professor Tatjana van Strien for her suggestions on the writing of this manuscript. This study was partially supported by "Comisión Nacional de Investigación Científica y Tecnológica (CONICYT)" from Chile.
} 


\section{Introduction}

Obesity has become one of the most serious public health problems in Western nations. A key factor that contributes to the development and maintenance of overweight and obesity is the obesogenic environment (Swinburn, Egger, \& Raza, 1999), one in which the combination of an abundant availability of food and declining physical activity interacts with genetic susceptibility to promote a positive energy balance, weight gain and, ultimately, excess weight (van Strien, Herman, \& Verheijden, 2012). With rates of overweight and obesity constantly increasing worldwide, many people are resorting to various dieting strategies (Houben, Nederkoorn, \& Jansen, 2012). However, attempts to reduce body weight over an extended period of time seem difficult to maintain for most people, and most of the weight lost is usually regained (Aphramor, 2010; Chaput et al., 2009; Mann et al., 2007; Saris \& Harper, 2005).

In recent decades several psychological theories have been developed in an attempt to explain why some people eat more than others (Bozan, Bas, \& Asci, 2011). One of these theories is restraint theory (Herman \& Polivy, 1980), which for more than 30 years has been the prominent theoretical perspective concerning the self-control of eating and weight (Stotland, 2012). Despite its limited efficacy as a method of reducing weight in the long-term, dietary restraint is widely advocated as the treatment of choice for obesity (Verweij, Coffeng, van Mechelen, \& Proper, 2011). One of the problems with dietary restraint is that it is often associated with overeating tendencies and, as a consequence, with weight gain (Chaput et al., 2009; Goldsmith et al., 2010; Polivy \& Herman, 1985). In addition, emotional and external eating behavior can complicate the association between dietary restraint, food intake and change in body weight (van Strien et al., 2012). Emotional eating refers to the tendency to overeat in response to negative emotions as a result of poor interoceptive awareness, a notion derived from Bruch's (1964) psychosomatic theory (van Strien et al., 2012). More generally, emotional eating has been defined as eating in response to emotional cues, often as a way of coping with negative emotions (Bennett, Greene, \& Schwartz-Barcott, 2013; Goldbacher et al., 2012), and as such it is associated with weight gain (Sung, Lee, Song, Lee, \& Lee, 2010). The concept of external eating has its origin in the externality theory of obesity that was developed by Schachter in the 1960s (Schachter, 1968), one which refers to the tendency to eat when exposed to food-related cues such as the sight, smell or taste of food, even in the absence of physiological hunger (Nijs, Franken, \& Muris,
2009). In the current obesogenic environment, in which attractive food is omnipresent and readily accessible, an external eating style might be an important vulnerability factor in relation to overeating and, therefore, to becoming overweight or obese (Nijs et al., 2009).

These three types of eating behavior - dietary restraint, emotional eating and external eating — can be accurately assessed by means of the Dutch Eating Behavior Questionnaire (DEBQ) (van Strien, Frijters, Bergers, \& Defares, 1986), which has been adapted to be applied in several settings, especially in eating disorders and obesity in clinical and community samples (Bailly, Maitre, Amanda, Herve, \& Alaphilippe, 2012; Baños et al., 2011; Bozan et al., 2011; Cebolla, Barrada, van Strien, Oliver, \& Baños, 2014; Halvarsson \& Sjoden, 1998; Lluch et al., 1996; van Strien \& Oosterveld, 2008; Wardle, 1987). Research with different adult samples has reported adequate psychometric properties for the questionnaire, not just in its original version (van Strien et al., 1986) but also in its adaptation to English (Wardle, 1987), French (Lluch et al., 1996), Turkish (Bozan et al., 2011), Italian (Dakanalis et al., 2013), and Spanish (Cebolla et al., 2014). Several studies support the adequate internal consistency of the questionnaire in adult samples (Barrada, van Strien, \& Cebolla, 2013; Bozan et al., 2011; Cebolla et al., 2014; Dakanalis et al., 2013; Lluch et al., 1996; van Strien et al., 1986; van Strien \& Koenders, 2012), as well as its three-factor internal structure measuring dietary restraint, emotional eating and external eating (Barrada et al., 2013; Bozan et al., 2011; Cebolla et al., 2014; Dakanalis et al., 2013; Lluch et al., 1996; van Strien et al., 1986).

A gender effect has also been found, with women scoring higher than men on the DEBQ (Dakanalis et al., 2013; Pothos, Tapper, \& Calitri, 2009; Wardle, 1987). Consistent with the fact that these types of eating behavior assessed by the DEBQ are associated with weight gain, several studies (Pothos et al., 2009; van Strien, Herman, \& Verheijden, 2009) have also shown that DEBQ scores are associated with higher body mass index (BMI). Finally, there is evidence of an association between DEBQ scores and several self-report measures of eating disorder symptoms (Bozan et al., 2011).

However, there is a lack of research assessing the Spanish version of this questionnaire specifically applied to Chilean population, which presents culture differences compared to other Spanish-speaking populations in which the DEBQ has been applied. Moreover, no studies to date have tested the psychometric properties of this questionnaire in a community sample of males and females presenting a wide range of age and BMI. Although Chile and Spain share 
a language, there are profound cultural differences between the two countries, especially in relation to feeding and eating behaviors. Because of these differences, it is important to conduct country-specific psychometric analyses of assessment instruments like the DEBQ. Chile, unlike Spain, is a developing country with a social model similar to the one prevailing in the US, where traditional food has been replaced by high consumption of fast food rich in trans fats and sugars, high rates of sedentary lifestyle, overweight and obesity in all age groups. In Spain, in contrast, the feeding model is based on the Mediterranean diet, characterized by, among other things, a preference for minimally processed foods (if possible fresh and grown locally), a high intake of vegetables, the use of olive oil as the principal source of fat and avoidance of animal fats. The Mediterranean diet is characterized by the way in which food is prepared, the relevance of the social act of eating, and moderation in the portions consumed (Oda-Montecinos, Andrés, \& Saldaña, 2014). Moreover, overweight and obesity rates continue to be significantly lower in Spain than in Chile. The most recent official data for overweight and obesity in Chile (Ministerio de Salud de Chile, 2011) showed that the average BMI of Chilean youth and adults was $26.9 \mathrm{~kg} / \mathrm{m}^{2}$ in men, $27.9 \mathrm{~kg} /$ $\mathrm{m}^{2}$ for women and $27.4 \mathrm{~kg} / \mathrm{m}^{2}$ overall - all values in the overweight range. In addition, $64.5 \%$ of the population had $\mathrm{BMI} \geq 25 \mathrm{~kg} / \mathrm{m}^{2} ; 39.32 \%$ were overweight $(25 \leq \mathrm{BMI} \leq$ $29.99 \mathrm{~kg} / \mathrm{m}^{2}$ ) and $25.13 \%$ obese (BMI $\left.\geq 30 \mathrm{~kg} / \mathrm{m}^{2}\right)$.

The main objective of the present study was to analyse the psychometric properties of the DEBQ in a sample of normal weight, overweight and obese Chilean adults. The specific aims of the study were: a) to carry out an analysis of DEBQ items, b) to assess the internal structure of the questionnaire by means of a cross-validation analysis, c) to analyse the internal consistency of the scale, d) to assess the possible relationship between DEBQ scores and both gender and BMI, and e) to obtain evidence about the convergent validity of the questionnaire.

\section{Methods}

\section{Participants}

This was a community sample of 627 adults from Rancagua and Santiago in Chile. In order to be eligible for inclusion, participants had to be at least 18 years old and to have a BMI $\geq 18.5 \mathrm{~kg} / \mathrm{m}^{2}$. As shown in Table 1 , the

Table 1. Sociodemographic characteristics of participants

\begin{tabular}{llll}
\hline & $\begin{array}{l}\text { Women } \\
(\mathrm{n}=415)\end{array}$ & $\begin{array}{l}\text { Men } \\
(\mathrm{n}=212)\end{array}$ & $\begin{array}{l}\text { Total } \\
(\mathrm{n}=627)\end{array}$ \\
\hline Age* & $36.60(12.48)$ & $35.04(12.50)$ & $36.07(12.50)$ \\
& $18-64$ & $18-64$ & $18-64$ \\
BMI* & $25.14(4.40)$ & $26.53(3.64)$ & $25.61(4.20)$ \\
& $18.73-50.60$ & $19.14-38.76$ & $18.73-50.60$ \\
BMI categories** & & & \\
Normal weight & 58.1 & 35.4 & 50.4 \\
Overweight & 28.9 & 50.0 & 36.0 \\
Obesity & 13.0 & 14.6 & 13.6 \\
Educational level** & & & \\
School education incomplete & 3.1 & .9 & 2.4 \\
School education complete & 12.5 & 11.3 & 12.1 \\
Technical education incomplete & 2.2 & .5 & 1.6 \\
Technical education complete & 18.8 & 10.8 & 16.1 \\
University education incomplete & 16.9 & 25.9 & 19.9 \\
University education complete & 46.5 & 50.5 & 47.8 \\
Socio-economical level** & & & \\
Quintile I & 3.4 & 1.4 & 2.7 \\
Quintile II & 4.6 & 3.3 & 4.1 \\
Quintile III & 7.0 & 4.7 & 6.2 \\
Quintile IV & 15.9 & 17.0 & 16.3 \\
Quintile V & 65.5 & 70.3 & 67.1 \\
\hline
\end{tabular}

Note. * Cells represent means, SDs, and ranges, ** Cells represent percentages. 
mean age of the sample was 36.07 years $(\mathrm{SD}=12.49)$, the majority $(66.2 \%)$ were women, and BMI ranged from 18.73 to $50.60 \mathrm{~kg} / \mathrm{m}^{2}\left(\right.$ mean $\left.=25.61 \mathrm{~kg} / \mathrm{m}^{2}, \mathrm{SD}=4.20\right)$. Half of the participants $(50.6 \%)$ were normal weight $(18.5 \geq \mathrm{BMI} \leq$ $24.99), 36.0 \%$ of them were overweight $(25 \geq \mathrm{BMI} \leq 29.99)$ and $13.4 \%$ were obese $(\mathrm{BMI} \geq 30)$. In terms of education, $12.1 \%$ of the sample had only completed school education, $16.1 \%$ had finished technical education and $67.7 \%$ had higher education qualifications. Taking into consideration the epidemiologic data of overweight and obesity in Chile, the prevalence rates in the present study were lower than those found in the general population (with the exception of overweight in men).

Socioeconomic level was defined by means of quintiles, one of the socioeconomic indicators most frequently used in Chile. This indicator consists in defining five socioeconomic levels depending on the household income per capita, with quintile 1 being the lowest income and quintile 5 the highest. Participants were assigned to one of five quintiles according to their economic status: $2.7 \%$ of them were thus located in the lowest quintile, $26.60 \%$ in the middle quintiles, and the majority $(67.1 \%)$ in the highest quintile.

\section{Materials and Procedure}

Participants completed the Spanish adaptation (Bach, 2002) of the DEBQ (van Strien et al., 1986). The DEBQ is a 33-item self-report instrument that aims to assess three types of eating behavior: dietary restraint (items 1 to 10 , 10 items), emotional eating (items 11 to 23,13 items) and external eating (items 24 to 33, 10 items). Items are responded to on a 5-point scale anchored by 'never' and 'very often'. One of the items (number 21) was reverse scored, and so while correcting the test the evaluator had to invert the scores: "never" answers were given 5 points and "always" answers 1 point. A pilot study was carried out to assess whether the items were adequate to be applied to Chilean population. Specifically, a convenience sample of 15 people from the community were asked to read the questionnaire and to assess whether the items were easy to understand. No changes were conducted due to nuances in language. The DEBQ has been shown to have adequate psychometric properties in Dutch, British, French, Turkish, and Spanish samples of adults and adolescents (Bozan et al., 2011; Cebolla et al., 2014; Lluch et al., 1996; van Strien et al., 1986; Wardle, 1987).

Participants also completed the Drive for thinness, Bulimia and Body dissatisfaction subscales of the Eating Disorder Inventory-2 (EDI-2) (Garner, 1991), and the Dieting subscale of the Eating Attitudes Test-40 (EAT-40) (Garner \& Garfinkel, 1979). Previous studies support the adequate psychometric properties of these subscales in several settings (Castro, Toro, Salamero, \& Guimerá, 1991; Garner \& Garfinkel, 1979; Garner, 1991; Podar \& Allik, 2009; Rayon, Arevalo, Diaz, \& Gomez-Peresmitre, 2002).

The study was approved by the ethics committee of the Rancagua Regional Hospital, where recruitment took place. Hospital staff were invited to participate in the study, and were approached directly by the researchers. A convenience sample of adults from Santiago and Rancagua was also recruited from among people working in companies, universities or hospitals and also from the community at large. The people contacted were invited to participate and were informed of the study objectives and the time required to answer the questionnaires. No incentives were offered in return for participation. Once the participants agreed to respond, they were given the battery of instruments, and the day of collection was fixed, which ranged from waiting to reply immediately, give a few hours a day or at most a week to pick them up. Nine hundred questionnaires were distributed, of which 627 (69.67\%) were completed and included in the analysis. Just over a fifth of participants $(21.85 \%)$ were hospital staff and $78.15 \%$ were recruited from other sources.

Printed copies of the self-report questionnaire were provided to participants and returned to the researchers. All participants gave their written informed consent to participate in the study.

\section{Data analysis}

Descriptive, exploratory analyses and comparison of means were performed using IBM SPSS Statistics 20 software, with AMOS 20 software being used to conduct the confirmatory factor analysis (CFA).

A descriptive analysis of items was first performed to assess whether items were appropriate for assessing dietary restraint, emotional eating and external eating in this specific sample. The following criteria were established to evaluate the appropriateness of items: missing percentage $<5 \%$ (Guarino, Lamping, Elbourne, Carpenter, \& Peduzzi, 2006), maximum endorsement frequency (MEF) $<80 \%$ (Ware, Gandek, \& IQOLA Project Group, 1998), corrected item-total subscale correlation $\geq .40$ and moderate inter-item correlations (Guarino et al., 2006).

The next step involved carrying out a cross-validation analysis in order to assess the internal structure of the questionnaire, as suggested by Floyd and Widaman (Floyd \& Widaman, 1995). Participants were then randomly assigned 
to two subsamples. Comparison of means revealed no statistically significant differences between the two samples in terms of age or BMI. Moreover, the chi-square test showed no significant difference in the proportion of men and women in the two samples. A principal component analysis (PCA) with Varimax rotation was then carried out with the first subsample $(n=314)$. Factors were retained on the basis of the scree plot and the Kaiser-Guttman rule (Kaiser, 1960), which suggests keeping those factors with eigenvalues greater than 1.0. A CFA was then conducted with the second sample $(n=313)$, based on the results obtained in the PCA. Multivariate normality of data was tested by means of Mardia's estimate for multivariate kurtosis (Mardia, 1970). According to Bentler (Bentler, 2005), values above 5.0 for Mardia's normalized estimate are indicative of non-normal data. Since our data were non-normal, the unweighted least squares (ULS) estimation method was applied. The following goodness-of-fit indices were calculated: chi-square test, goodness-of-fit index (GFI), adjusted goodness-of-fit index (AGFI) (Joreskog \& Sorbom, 1986), parsimony goodnessof-fit index (PGFI) (Mulaik et al., 1989), normed fit index (NFI) (Bentler \& Bonett, 1980) and the standardized root mean square residual (SRMR) (Joreskog \& Sorbom, 1986). The cut-off values for determining a good fit were $\geq .90$ for the GFI, AGFI and NFI (Jackson, Gillaspy, \& PurcStephenson, 2009), .60 for the PGFI (Mulaik et al., 1989) and $\leq .08$ for the SRMR (Hu \& Bentler, 1999).

A reliability analysis was then conducted for both samples by calculating Cronbach's alpha coefficients and corrected item-total correlations, applying the criteria of Nunnally and Bernstein (Nunnally \& Bernstein, 1994).

Finally, the scores obtained on the DEBQ subscales were analysed in relation to the other variables considered. Specifically, the Student's t test was applied to assess gender differences in relation to DEBQ scores, while two-way analysis of variance (ANOVA) and Tukey post hoc comparisons were used to assess differences in DEBQ scores across BMI groups. Pearson's correlations were calculated to assess the relationship between DEBQ scores and those obtained on the EDI-2 and EAT-40 subscales.

\section{Results}

\section{Item analysis}

A descriptive analysis of items was carried out to assess the adequacy of items in the whole sample $(n=627)$. According to the abovementioned criteria, none of the items showed a high percentage of missing responses or a high MEF. However, item 21 showed a very low corrected item-total correlation $(r=.080)$, suggesting that responses to this item were not positively correlated with the score obtained on the external eating subscale as a whole. Moreover, the correlation analysis revealed that item 21 yielded low correlations with respect to the other items of this subscale (ranging from -.050 to .182), and only showed a statistically significant relationship to two other items measuring external eating. It has to be noted that this item was a reversed-key item.

\section{Internal structure}

A PCA was applied to sample $1(\mathrm{n}=314)$. The KaiserMeyer-Olkin index (KMO) and Bartlett's test of sphericity confirmed the adequacy of the data for factor analysis $\left(\mathrm{KMO}=.916, \chi_{(528)}^{2}=7047.51, \mathrm{p}<.0001\right)$, which yielded a five-factor solution, according to the Kaiser-Guttman rule. However, examination of the scree plot suggested that a smaller number of factors should be retained. Given that two of the five factors accounted for a very small proportion of the variance, and in light of the results obtained by other authors in previous psychometric analysis of the DEBQ, alternative models of three and four factors were tested. The three-factor solution led to a more suitable and interpretable version of the scale. Furthermore, the content analysis of factors revealed that items belonging to the same subscale were indeed measuring similar content. The percentage of explained variance of this three-factor model was $56.93 \%$, with communalities ranging between .314 and .794 , with the exception of item 21 , which had a communality value of .074. Factor loadings of items are shown in Table 2. As recommended by Floyd and Widaman (Floyd \& Widaman, 1995), factor loadings of .30 were considered acceptable. All items reached acceptable factor loadings, with the exception of item 21 - the only item that had to be reverse scored - which did not load on any of the three factors. Two items (3 and 28) showed cross-loadings (higher to .30) in two factors. Loadings were high in value in the theoretical factor where they corresponded (even in those items showing cross-loadings), ranging from .556 to .829 in the emotional eating factor, from .592 to .791 in the external eating factor (with the exception of item 21), and finally from .595 to .876 in the dietary restraint subscale. Given the results obtained both in the item analysis and the PCA, item 21 was not included in the subsequent analyses. 
Table 2. Factor loadings of DEBQ items as obtained in the principal components analysis

\begin{tabular}{|c|c|c|c|c|c|}
\hline & & Communalities & & Factor loadings & \\
\hline & Item wording ${ }^{\mathrm{a}}$ & & Emotional eating & External eating & Dietary restraint \\
\hline 1. & Desire to eat when irritated & .585 & .719 & .256 & .053 \\
\hline 2. & Eat more than usual when tasty & .429 & .144 & 639 & -.007 \\
\hline 3. & Desire to eat when nothing to do & .480 & .595 & .346 & .079 \\
\hline 4. & Eat less than usual when gained weight & .534 & .065 & .082 & .723 \\
\hline 5. & Desire to eat when you feel depressed & .708 & .798 & .258 & .067 \\
\hline 6. & Eat more than normal when food is good & .566 & .126 & .741 & -.028 \\
\hline 7. & Reject food or drinks because worry about weight & .622 & .199 & -.082 & .759 \\
\hline 8. & Eating when you feel lonely & .610 & .725 & .241 & .164 \\
\hline 9. & Desire to eat when delicious & .649 & .151 & .791 & -.012 \\
\hline 10. & Desire to eat when somebody lets you down & .794 & .865 & .153 & .146 \\
\hline 11. & Eat less during meal times & .594 & .158 & .099 & .748 \\
\hline 12. & Eat it immediately when delicious & .534 & .137 & .718 & -.021 \\
\hline 13. & Desire to eat when angry & .698 & .812 & .166 & .103 \\
\hline 14. & Watch what you eat & .314 & -.014 & .068 & .556 \\
\hline 15. & Desire to eat something delicious & .520 & .213 & .688 & -.029 \\
\hline 16. & Desire to eat when unpleasant & .661 & .795 & .148 & .081 \\
\hline 17. & Eat foods that are slimming & .585 & .180 & .121 & .733 \\
\hline 18. & Desire to eat when others eating & .474 & .208 & .656 & -.007 \\
\hline 19. & Eating less after eating too much & .479 & .063 & .041 & 688 \\
\hline 20. & Desire to eat when anxious & .635 & .786 & .133 & .017 \\
\hline 21. & Difficult to resist delicious food & .074 & .166 & .064 & -.207 \\
\hline 22. & Eat less deliberately & .691 & .063 & .002 & .829 \\
\hline 23. & Desire to eat when things go against you & .793 & .876 & .150 & .052 \\
\hline 24. & Desire to buy food when bar & .503 & .207 & .677 & .032 \\
\hline 25. & Desire to eat when upset & .750 & .861 & .097 & .004 \\
\hline 26. & Not to eat because watching your weight & .603 & -.056 & -.026 & .774 \\
\hline 27. & Eat more than usual when others eating & .416 & .183 & .592 & .179 \\
\hline 28. & Desire to eat when bored & .563 & .680 & .304 & .087 \\
\hline 29. & Try not to eat in evening because watching weight & .496 & .024 & .079 & 699 \\
\hline 30. & Desire to eat when frightened & .702 & .835 & .022 & .055 \\
\hline 31. & Take into account weight when eat & .545 & .127 & -.045 & .726 \\
\hline 32. & Desire to eat when disappointed & .784 & .874 & .137 & .032 \\
\hline 33. & Eating when preparing meal & .396 & .095 & .603 & .153 \\
\hline & Eigenvalues & & 10.48 & 3.23 & 5.07 \\
\hline
\end{tabular}

Note. Factor loadings $>.40$ are in boldface.

${ }^{a}$ Exact item wording cannot be shown due to copyright restrictions. 
A CFA was then applied to sample $2(n=313)$ in order to test the three-factor structure obtained previously. The data were shown not to fit multivariate normality, since Mardia's estimate for multivariate kurtosis was 51.76, and therefore the ULS estimation method was applied. The following goodness-of-fit indices were obtained: $\chi_{(461)}^{2}=$ $1055.85, \mathrm{p}<.0001 ; \mathrm{GFI}=.979 ; \mathrm{AGFI}=.977 ; \mathrm{PGFI}=.855$; $\mathrm{NFI}=.974 ;$ and SRMR $=.0581$. These values indicated that the data showed a good fit. Standardized regression weights ranged from .542 to .813 for the dietary restraint subscale, similar to that obtained for the emotional eating subscale (from .703 to .854). On the external eating scale, standardized regression weights ranged from .509 to .846 . The analysis of correlations between factors revealed that scores obtained on the emotional and external eating subscales were highly correlated $(\mathrm{r}=.531, \mathrm{p}<.0001)$. Similar results were obtained regarding the dietary restraint and emotional eating subscales $(\mathrm{r}=.258, \mathrm{p}<.05)$. Finally, no statistically significant differences were found between dietary restraint and external eating scores $(\mathrm{r}=.077, \mathrm{p}=.181)$.

\section{Internal consistency}

Corrected item-total correlations and Cronbach's alpha were calculated in both samples, as shown in Table 3. Cronbach's alpha reached acceptable values (ranging from .870 to .970$)$ on all subscales in both samples. Corrected item-total correlations were also acceptable in all cases and in both samples (ranging from .476 to .846), which indicated that all items contributed to the internal consistency of the scale.

\section{Relationship with other variables}

The first relationship assessed was that between scores obtained on the DEBQ and socio-demographic variables (gender and BMI). In addition, we analysed the correlations between DEBQ scores and the abovementioned EDI-2 and EAT-40 subscales in order to obtain evidence about the convergent validity of the scale.

A gender effect was observed for the dietary restraint $(\mathrm{t}(614)=4.41, \mathrm{p}<.0001)$ and emotional eating $(\mathrm{t}(490.20)=$ $4.38, \mathrm{p}<.0001)$ subscales. However, there was no significant gender effect in relation to the external eating subscale $(t$ $(622)=-.465, \mathrm{p}=.642)$.

Differences in DEBQ scores across BMI groups and gender were tested by means of a two-way ANOVA. The following BMI groups were considered: normal weight $\left(18.5 \geq \mathrm{BMI}<25 \mathrm{~kg} / \mathrm{m}^{2}\right)$, overweight $(25 \geq \mathrm{BMI}<30 \mathrm{~kg} /$ $\left.\mathrm{m}^{2}\right)$ and obese $\left(\mathrm{BMI} \geq 30 \mathrm{~kg} / \mathrm{m}^{2}\right)$. Analyses revealed that gender and BMI categories had a significant effect on the scores on the Eating restraint subscale $\left(\mathrm{F}_{\text {gender }(5,616)}=18.246\right.$, $\mathrm{p}<.0001 ; \mathrm{F}_{\mathrm{BMI}(5,616)}=12.147, \mathrm{p}<.0001 ; \mathrm{F}_{\text {gender*BMI }(5,616)}=$ $3.054, p=.048)$. Specifically, it was found that normal weight and overweight women scored significantly higher

Table 3. Internal consistency analysis

\begin{tabular}{lcccccc}
\hline & \multicolumn{3}{c}{ Sample 1 $(\mathrm{n}=314)$} & \multicolumn{3}{c}{ Sample 2 $(\mathrm{n}=313)$} \\
\cline { 2 - 7 } & $\alpha$ & $\begin{array}{c}\text { I-T corr } \\
\text { (range) }\end{array}$ & $\begin{array}{c}\text { I-T corr } \\
\text { (mean) }\end{array}$ & $\alpha$ & $\begin{array}{c}\text { I-T corr } \\
\text { (range) }\end{array}$ & $\begin{array}{c}\text { I-T corr } \\
(\text { mean })\end{array}$ \\
\hline Dietary restraint & .899 & $.476-.700$ & .653 & .902 & $.563-.792$ & .660 \\
Emotional eating & .953 & $.644-.846$ & .773 & .960 & $.702-.845$ & .794 \\
External eating & .870 & $.513-.718$ & .605 & .892 & $.497-.714$ & .653 \\
\hline
\end{tabular}

Note. $I$-T corr $=$ Item-total correlations.

Table 4. Correlations between DEBQ scores and external measures

\begin{tabular}{llcccc}
\hline & & \multicolumn{2}{c}{ EDI-2 } & \multicolumn{2}{c}{ EAT-40 } \\
\cline { 3 - 5 } & & Drive for thinness & Bulimia & $\begin{array}{c}\text { Body } \\
\text { dissatisfaction }\end{array}$ & Diet \\
\hline \multirow{3}{*}{ DEBQ } & Dietary restraint & $.574^{* *}$ & .028 & $.237^{* *}$ & $.665^{* *}$ \\
& Emotional eating & $.359^{* *}$ & $.432^{* *}$ & $.302^{* *}$ & $.335^{* *}$ \\
& External eating & $.149^{* *}$ & $.386^{* *}$ & $.174^{* *}$ & $.099^{*}$ \\
\hline
\end{tabular}

Note. $* p<.05, * * p<.0001$. 
on this scale than normal weight and overweight men $(\mathrm{p}<$ .0001 and $p=.033$ respectively). The same relationship was observed in the subscale of emotional eating $(p<.016$ in the normal weight group, and $p<.0001$ in the overweight group), although the interaction did not have a statistically significant effect on the scores on this subscale.

The analysis of correlations between DEBQ scores and those on the EDI-2 and EAT-40 subscales revealed a statistically significant relationship between most of these self-reported measures (Table 4). Specifically, higher dietary restraint scores were associated with higher scores on the drive for thinness and body dissatisfaction subscales of the EDI-2 and the dieting subscale of the EAT-40, thereby supporting the convergent validity of the questionnaire. However, no statistically significant correlation was found between the DEBQ dietary restraint score and the bulimia subscale of the EDI-2.

\section{Discussion}

The present study is the first to apply the DEBQ to a community sample of Chilean adults and, subsequently, to assess the psychometric properties of the questionnaire in this setting. In contrast to previous studies, the present research considered a community sample of males and females with a wide range of age and BMI. Furthermore, it is the first study focused on the application of the DEBQ to Chilean population, which presents culture specific features compared to the Spanish population in which this questionnaire has already been tested. Therefore, the present study represents a significant contribution to the literature on the use of the DEBQ to assess eating behavior. The results are based on a large community sample of men and women of a wide range of ages, whereas the results of the Spanish version of the questionnaire are based on a college sample of women.

Both the item analysis and the PCA revealed that one of the items was not suitable for measuring external eating in this population. Specifically, item 21 showed a low corrected item-total correlation as well as low factor loading. A similar result was found in the French adaptation of the DEBQ (Lluch et al., 1996), where the same item obtained a low factor loading on its corresponding subscale. Several authors (Cebolla et al., 2014; Lluch et al., 1996) suggested that a possible explanation for this was that this item is the only one that is reverse scored. In fact, in the study of Cebolla et al.(2014), item 21 was reformulated to read positively, like the rest of the questionnaire items.
The results obtained in the cross-validation analysis indicated that a three-factor model provided the best fit for the internal structure of the DEBQ. Similarly to other studies, application of the Kaiser-Guttman criterion initially suggested a five-factor model, but a three-factor solution led to a more suitable and interpretable version of the scale in the PCA (Lluch et al., 1996; Wardle, 1987). Similar to results found by Cebolla et al.(2014), items 3 and 28 showed crossloadings to two different factors. However, item loadings in the present sample were high in value in the theoretical factor where they corresponded. The goodness-of-fit indices, including the SRMR, that were calculated for the subsequent CFA confirmed that a three-factor model adequately explained the internal structure of the questionnaire. The correlations obtained between subscales were similar to those reported in other studies (Cebolla et al., 2014; van Strien et al., 1986), where the highest correlation was that between the emotional eating and external eating subscales $(\mathrm{r}=.48)$, followed by the correlation between dietary restraint and emotional eating $(\mathrm{r}=.37)$, and, finally, that between dietary restraint and external eating $(\mathrm{r}=.16)$.

As regards the internal consistency of the scale, this was adequate (ranging from .870 to .970 ) for all the subscales, thereby indicating that the DEBQ is a reliable self-report measure to assess dietary restraint, emotional eating and external eating in the Chilean population. Internal consistency indices obtained in the present study were similar to those found in other adult samples (Bozan et al., 2011; Cebolla et al., 2014; Dakanalis et al., 2013; Lluch et al., 1996; van Strien et al., 1986; van Strien \& Koenders, 2012).

The analysis of the relationship between DEBQ scores and other variables produced similar findings to previous studies. First, a gender effect was found for the dietary restraint and emotional eating subscales, with women scoring higher than men. This pattern was also reported in both the English (Wardle, 1987) and Italian validations of the questionnaire (Dakanalis et al., 2013). Many other studies have likewise shown a gender effect in relation to DEBQ scores, with the exception of those on the external eating dimension (Burton, Smit, \& Lightowler, 2007; Greene et al., 2011; Konttinen, Haukkala, Sarlio-Lahteenkorva, Silventoinen, \& Jousilahti, 2009; Pothos et al., 2009; van Strien et al., 2009).

The present analysis also revealed a significant effect of sex and BMI on the eating restraint subscale, with normal weight and overweight women scoring significantly higher than normal weight and overweight men. A BMI effect was also found in the emotional eating subscale, although no interaction with sex was observed. These results are 
in line with those reported by other authors (Bozan et al., 2011; Cebolla et al., 2014) when assessing the psychometric properties of the DEBQ in other adults samples. The lack of relationship between BMI and external eating has been discussed by Herman and Polivy (2008), who find this result somewhat surprising given the possible role of environmental (external) food cues in the development of overweight. It should be noted, however, that the absence of any difference between overweight and normal weight people in terms of external eating has been widely reported (Pothos et al., 2009; Sung, Lee, \& Song, 2009; van Strien, Herman, Engels, Larsen, \& van Leeuwe, 2007; van Strien et al., 2009; van Strien \& Koenders, 2012), which would suggest that external eating is a characteristic of the general population rather than being specific to overweight individuals (Pothos et al., 2009). Finally, and in accordance with the results of Bozan et al.(2011) and Cebolla et al.(2014), significant correlations were found between DEBQ scores and other eating disorder measures, thereby supporting the convergent validity of the scale.

The limitations of the present study are related to the measurement instruments used and the sampling procedure. The use of a non-probabilistic sampling procedure, the collection of data through self-reported questionnaires - including anthropometric measures - are limitations that must be taken into consideration before generalizing the results to other contexts. However, previous work has found self-reported weight and height measures to be reliable (Lora-Cortez \& Saucedo-Molina, 2006).

In conclusion, the results of the present study support the reliability and validity of the DEBQ for assessing dietary restraint, emotional eating and external eating in the Chilean population. The results support the three-factor structure of the questionnaire and provide evidence of the scale's adequate internal consistency and convergent validity. The analysis identified one item that showed low loadings in any factor, as previously noted by other authors. The reformulation of this item in its forward scoring has been introduced in recent applications of the questionnaire. The findings are also consistent with previous reports regarding correlations between DEBQ scores and variables such as gender and BMI.

\section{References}

Aphramor, L. (2010). Validity of claims made in weight management research: a narrative review of dietetic articles. Nutrition Journal, 9 , 30. http://doi.org/10.1186/1475-2891-9-30
Bach, L. (2002). Conocimiento nutricional y conductas de control de peso - Nutrition knowledge and weight control behaviors(doctoral dissertation). University of Barcelona.

Bailly, N., Maitre, I., Amanda, M., Herve, C., \& Alaphilippe, D. (2012). The Dutch Eating Behaviour Questionnaire (DEBQ). Assessment of eating behaviour in an aging French population. Appetite, 59, 853-858. http://doi.org/10.1016/j.appet.2012.08.029

Baños, R. M., Cebolla, A., Etchemendy, E., Felipe, S., Rasal, P., \& Botella, C. (2011). Validation of the Dutch Eating Behavior Questionnaire for children (DEBQ-C) for use with Spanish children. Nutrición Hospitalaria, 26, 890-898. http://doi.org/10.3305/nh.2011.26.4.5238

Barrada, J. R., van Strien, T., \& Cebolla, A. (2013). Internal structure and measurement invariance of the Dutch Eating Behavior Questionnaire (DEBQ) in a Dutch community sample. Recovered from $<\mathrm{http}: / / \mathrm{www}$. unizar.es/barrada /papers/DEBQ Dutch sample.pdf> (submitted for publication).

Bennett, J., Greene, G., \& Schwartz-Barcott, D. (2013). Perceptions of emotional eating behavior. A qualitative study of college students. Appetite, 60, 187-192. http://doi.org/10.1016/j.appet.2012.09.023

Bentler, P. M. (2005). EQS 6 Structural Equations Program Manual. Encino, LA: Multivariate Software.

Bentler, P. M., \& Bonett, D. G. (1980). Significance Tests and Goodness of Fit in the Analysis of Covariance-Structures. Psychological Bulletin, 88, 588-606. http://doi.org/10.1037/0033-2909.88.3.588

Bozan, N., Bas, M., \& Asci, F. H. (2011). Psychometric properties of Turkish version of Dutch Eating Behaviour Questionnaire (DEBQ). A preliminary results. Appetite, 56, 564-566. http://doi.org/10.1016/j. appet.2011.01.025

Bruch, H. (1964). Psychological aspects in overeating and obesity. Psychosomatics, 5, 269-274.

Burton, P., Smit, H. J., \& Lightowler, H. J. (2007). The influence of restrained and external eating patterns on overeating. Appetite, 49, 191-197. http://doi.org/10.1016/j.appet.2007.01.007

Castro, J., Toro, J., Salamero, M., \& Guimerá, E. (1991). The Eating Attitudes Test: Validation of the Spanish version. Evaluación Psicológica, 7, 175-189.

Cebolla, A., Barrada, J. R., van Strien, T., Oliver, E., \& Baños, R. (2014). Validation of the Dutch Eating Behavior Questionnaire (DEBQ) in a sample of Spanish women. Appetite, 73, 58-64. http://doi.org/10.1016/j. appet.2013.10.014

Chaput, J.-P., Leblanc, C., Perusse, L., Despres, J.-P., Bouchard, C., \& Tremblay, A. (2009). Risk Factors for Adult Overweight and Obesity in the Quebec Family Study: Have We Been Barking Up the Wrong Tree? Obesity, 17, 1964-1970. http://doi.org/10.1038/oby.2009.116

Dakanalis, A., Zanetti, M. A., Clerici, M., Madeddu, F., Riva, G., \& Caccialanza, R. (2013). Italian version of the Dutch Eating Behavior Questionnaire. Psychometric proprieties and measurement invariance across sex, BMI-status and age. Appetite, 71, 187-195.

Floyd, F. J., \& Widaman, K. F. (1995). Factor analysis in the development and refinement of clinical assessment instruments. Psychological Assessment, 7, 286-299. http://doi.org/10.1037/1040-3590.7.3.286

Garner, D. M. (1991). Eating disorder inventory-2: Professional manual. Psychological Assessment Resources Odessa, FL.

Garner, D. M., \& Garfinkel, P. E. (1979). Eating Attitudes Test - Index of the Symptoms of Anorexia-Nervosa. Psychological Medicine, 9, 273-279.

Goldbacher, E. M., Grunwald, H. E., LaGrotte, C. A., Klotz, A. A., Oliver, T. L., Musliner, K. L., ... Foster, G. D. (2012). Factor structure of the Emotional Eating Scale in overweight and obese adults seeking treatment. Appetite, 59, 610-615. http://doi.org/10.1016/j. appet.2012.04.005

Goldsmith, R., Joanisse, D. R., Gallagher, D., Pavlovich, K., Shamoon, E., Leibel, R. L., \& Rosenbaum, M. (2010). Effects of experimental weight perturbation on skeletal muscle work efficiency, fuel utilization, and biochemistry in human subjects. American Journal of PhysiologyRegulatory Integrative and Comparative Physiology, 298, R79-R88. http://doi.org/10.1152/ajpregu.00053.2009

Greene, G. W., Schembre, S. M., White, A. A., Hoerr, S. L., Lohse, B., Shoff, S., ... Blissmer, B. (2011). Identifying Clusters of College 
Students at Elevated Health Risk Based on Eating and Exercise Behaviors and Psychosocial Determinants of Body Weight. Journal of the American Dietetic Association, 111, 394-400. http://doi.org/10.1016/j. jada.2010.11.011

Guarino, P., Lamping, D. L., Elbourne, D., Carpenter, J., \& Peduzzi, P. (2006). A brief measure of perceived understanding of informed consent in a clinical trial was validated. Journal of Clinical Epidemiology, 59, 608-614. http://doi.org/10.1016/j.jclinepi.2005.11.009

Halvarsson, K., \& Sjoden, P. O. (1998). Psychometric properties of the Dutch Eating Behaviour Questionnaire (DEBQ) among 9-10-yearold Swedish girls. European Eating Disorders Review, 6, 115-125. http://doi.org/10.1002/(SICI)1099-0968(199806)6:2<115::AIDERV222>3.0.CO;2-M

Herman, C. P., \& Polivy, J. (1980). Restrained eating. In A. J. Stunkard (Ed.), Obesity (pp. 208-225). Philadelphia: Sanders.

Herman, C. P., \& Polivy, J. (2008). External cues in the control of food intake in humans: the sensory-normative distinction. Physiology \& Behavior, 94, 722-728.

Houben, K., Nederkoorn, C., \& Jansen, A. (2012). Too tempting to resist? Past success at weight control rather than dietary restraint determines exposure-induced disinhibited eating. Appetite, 59, 550-555. http://doi. org/10.1016/j.appet.2012.07.004

Hu, L. T., \& Bentler, P. M. (1999). Cutoff Criteria for Fit Indexes in Covariance Structure Analysis: Conventional Criteria Versus New Alternatives. Structural Equation Modeling-a Multidisciplinary Journal, 6, 1-55. http://doi.org/10.1080/10705519909540118

Jackson, D. L., Gillaspy, J. A., \& Purc-Stephenson, R. (2009). Reporting Practices in Confirmatory Factor Analysis: An Overview and Some Recommendations. Psychological Methods, 14, 6-23. http://doi. org $/ 10.1037 / \mathrm{a} 0014694$

Joreskog, K. G., \& Sorbom, D. (1986). LISREL IV: Analysis of linear structural relationships by maximum likelihood, instrumental variables and least squares methods. Science Software,. Mooresville, IN: Scientific Software Inc.

Kaiser, H. F. (1960). The Application of Electronic-Computers to FactorAnalysis. Educational and Psychological Measurement, 20, 141-151. http://doi.org/10.1177/001316446002000116

Konttinen, H., Haukkala, A., Sarlio-Lahteenkorva, S., Silventoinen, K., \& Jousilahti, P. (2009). Eating styles, self-control and obesity indicators. The moderating role of obesity status and dieting history on restrained eating. Appetite, 53, 131-134. http://doi.org/10.1016/j. appet.2009.05.001

Lluch, A., Kahn, J. P., StrickerKrongrad, A., Ziegler, O., Drouin, P., \& Mejean, L. (1996). Internal validation of a French version of the Dutch Eating Behaviour Questionnaire. European Psychiatry, 11, 198-203. http://doi.org/10.1016/0924-9338(96)88391-X

Lora-Cortez, I., \& Saucedo-Molina, T. (2006). Conductas alimentarias de riesgo e imagen corporal de acuerdo al índice de masa corporal en una muestra de mujeres adultas de la Ciudad de México. Salud Mental, 29, 60-67.

Mann, T., Tomiyama, A. J., Westling, E., Lew, A.-M., Samuels, B., \& Chatman, J. (2007). Medicare's search for effective obesity treatments - Diets are not the answer. American Psychologist, 62, 220-233. http:// doi.org/10.1037/0003-066X.62.3.220

Mardia, K. V. (1970). Measures of Multivariate Skewness and Kurtosis with Applications. Biometrika, 57, 519-530. http://doi.org/10.2307/2334770

Ministerio de Salud de Chile. (2011). Encuesta Nacional de Salud ENS Chile 2009-2010.

Mulaik, S. A., James, L. R., Vanalstine, J., Bennett, N., Lind, S., \& Stilwell, C. D. (1989). Evaluation of Goodness-Of-Fit Indexes for Structural Equation Models. Psychological Bulletin, 105, 430-445. http://doi. org/10.1037/0033-2909.105.3.430

Nijs, I. M. T., Franken, I. H. A., \& Muris, P. (2009). Enhanced processing of food-related pictures in female external eaters. Appetite, 53, 376-383. http://doi.org/10.1016/j.appet.2009.07.022

Nunnally, J. C., \& Bernstein, I. H. (1994). Psychometric theory. New York: McGraw-Hill.
Oda-Montecinos, C., Andrés, A., \& Saldaña, C. (2014). Estudio transcultural de los factores comportamentales asociados a la dieta mediterránea en jóvenes chilenos y españoles. In L. Valderrama \& B. Santander (Eds.), (pp. 722-738). Santiago de Chile.

Podar, I., \& Allik, J. (2009). A Cross-Cultural Comparison of the Eating Disorder inventory. International Journal of Eating Disorders, 42, 346-355. http://doi.org/10.1002/eat.20616

Polivy, J., \& Herman, C. P. (1985). Dieting and Binging - a Causal-Analysis. American Psychologist, 40, 193-201. http://doi.org/10.1037//0003066X.40.2.193

Pothos, E. M., Tapper, K., \& Calitri, R. (2009). Cognitive and behavioral correlates of BMI among male and female undergraduate students. Appetite, 52, 797-800. http://doi.org/10.1016/j.appet.2009.03.002

Rayon, G. A., Arevalo, R. V, Diaz, J. M. M., \& Gomez-Peresmitre, G. (2002). Evaluation of psychometric properties of the Eating Attitudes Test (EAT-40) in Mexican women. Revista Mexicana de Psicologia, $19,47-56$.

Saris, W. H. M., \& Harper, A. (2005). DiOGenes: a multidisciplinary offensive focused on the obesity epidemic. Obesity Reviews, 6, 175-176. http://doi.org/10.1111/j.1467-789x.2005.00200.x

Schachter, S. (1968). Obesity and Eating - Internal and External Cues Differentially Affect Eating Behavior of Obese and Normal Subjects. Science, 161, 751-\&. http://doi.org/10.1126/science.161.3843.751

Stotland, S. (2012). Moderation: An alternative to restraint as a mode of weight self-regulation. Eating Behaviors, 13, 406-409. http://doi. org/10.1016/j.eatbeh.2012. 07.001

Sung, J., Lee, K., \& Song, Y. M. (2009). Relationship of eating behavior to long-term weight change and body mass index: The Healthy Twin study. Eating and Weight Disorders-Studies on Anorexia Bulimia and Obesity, 14, E98-E105.

Sung, J., Lee, K., Song, Y.-M., Lee, M. K., \& Lee, D.-H. (2010). Heritability of Eating Behavior Assessed Using the DEBQ (Dutch Eating Behavior Questionnaire) and Weight-related Traits: The Healthy Twin Study. Obesity, 18, 1000-1005. http://doi.org/10.1038/oby.2009.389

Swinburn, B., Egger, G., \& Raza, F. (1999). Dissecting obesogenic environments: The development and application of a framework for identifying and prioritizing environmental interventions for obesity. Preventive Medicine, 29, 563-570. http://doi.org/10.1006/pmed.1999.0585

van Strien, T., Frijters, J. E. R., Bergers, G. P. A., \& Defares, P. B. (1986). The Dutch Eating Behavior Questionnaire (DEBQ) for assessment of restrained, emotional, and external eating behavior. International Journal of Eating Disorders, 5, 295-315.

van Strien, T., Herman, C. P., Engels, R. C. M. E., Larsen, J. K., \& van Leeuwe, J. F. J. (2007). Construct validation of the Restraint Scale in normal-weight and overweight females. Appetite, 49, 109-121. http:// doi.org/10.1016/j.appet.2007.01.003

van Strien, T., Herman, C. P., \& Verheijden, M. W. (2009). Eating style, overeating, and overweight in a representative Dutch sample. Does external eating play a role?. Appetite, 52, 380-387. http://doi. org/10.1016/j.appet.2008.11.010

van Strien, T., Herman, C. P., \& Verheijden, M. W. (2012). Eating style, overeating and weight gain. A prospective 2-year follow-up study in a representative Dutch sample. Appetite, 59, 782-789. http://doi. org/10.1016/j.appet.2012.08.009

van Strien, T., \& Koenders, P. G. (2012). How do life style factors relate to general health and overweight?. Appetite, 58, 265-270. http://doi. org/10.1016/j.appet.2011.10.001

van Strien, T., \& Oosterveld, P. (2008). The children's DEBQ for assessment of restrained, emotional, and external eating in 7- to 12-yearold children. International Journal of Eating Disorders, 41, 72-81. http://doi.org/10.1002/eat.20424

Verweij, L. M., Coffeng, J., van Mechelen, W., \& Proper, K. I. (2011). Meta-analyses of workplace physical activity and dietary behaviour interventions on weight outcomes. Obesity Reviews, 12, 406-429. http:// doi.org/10.1111/j.1467-789X.2010.00765.x

Wardle, J. (1987). Eating Style - a Validation-Study of the Dutch Eating Behavior Questionnaire in Normal Subjects and Women with Eating 
Disorders. Journal of Psychosomatic Research, 31, 161-169. http:// doi.org/10.1016/0022-3999(87)90072-9

Ware, J. E., Gandek, B., \& IQOLA Project Group. (1998). Methods for testing data quality, scaling assumptions, and reliability: The IQOLA project approach. Journal of Clinical Epidemiology, 51(11), 945-952. http://doi.org/10.1016/S0895-4356(98)00085-7 
